\title{
Established sectors expediting clean technology industries? The Norwegian oil and gas sector's influence on offshore wind power
}

Tuukka Mäkitie, Allan D. Andersen, Jens Hanson, Håkon E. Normann, Taran M. Thune Center for Technology, Innovation and Culture, University of Oslo, Norway P.O box 1108, Blindern, 0317 Oslo, Norway

\section{Post-print, published in Journal of Cleaner Production} https://doi.org/10.1016/j.jclepro.2017.12.209

Keywords:

technological innovation system; inter-industry relationships; sustainability transition; sectors; oil and gas industry.

Word count: 9773 (Including references, tables and captions; excluding abstract and title) 


\section{Introduction}

The world's endeavour to mitigate climate change and staying within a less than 2-degree warmer world is challenged by an enormous gap between what financial and technological resources are needed and what have thus far been committed to this task. In other words, significant acceleration in development and deployment of clean energy technologies currently constitutes a major policy challenge (EC, 2016; IEA, 2016). Mobilizing the vast resources of established industrial sectors to support cleantech industries is one possible way of meeting the challenge. This paper discusses how established sectors may positively influence the development of clean-tech industries.

Within studies on sustainability transitions in socio-technical systems (Markard et al., 2012), the relationships between established sectors and emerging cleantech industries have been studied in situations where established sectors react antagonistically to potentially disruptive innovations (Hess, 2013; Smink et al., 2015; Wesseling \& Van der Vooren, 2017). Recent contributions have, however, moved the research agenda beyond the dimension of conflict and competition, and now also focus on how established sectors could contribute to development and diffusion of clean technologies (Hockerts \& Wüstenhagen, 2010; Berggren et al., 2015; Dewald \& Achternbosch, 2016). Nevertheless, more knowledge about these processes is still needed.

We approach this issue by developing and applying an extended version of the technological innovation system (TIS) framework. The TIS framework is often used for analyzing emergence of cleantech industries by using a functions approach (Jacobsson \& Bergek, 2011; Markard et al., 2012). The approach has received criticisms for under-conceptualizing the context in which new industries form (Coenen \& Díaz López, 2010; Smith \& Raven, 2012). In response, TIS scholars have recently called for further attention to how TISs interact with different types of context, including other TISs, established sectors, geographical context, and politics (Bergek et al., 2015; Coenen, 2015; Kern, 2015; Andersen \& Markard, 2017).

Focusing on how established sectors influence TIS formation, we draw but also elaborate on these tentative observations to articulate an extension to the TIS framework. It is based on the notion of shared structural components - also referred to as overlaps - between the TIS and the established sector in the form of actors, institutions, networks and technology. Our main purpose is to explore the value and usefulness of this proposed framework through a case study from Norway. Our empirical research question therefore is: how does the established oil \& gas sector influence the nascent offshore wind TIS in Norway? Accentuating structural overlaps in TIS analysis can, we argue, help us to systematically attend to the ways in which context elements (here an established sector) influence a TIS in its formative stage. This enables us to understand parts of TIS formation that have not yet been fully appreciated. Our analysis thus contributes, firstly, to our understanding of formation of new clean technology industries in context of established sectors, and, secondly, to conceptual and methodological advancement in TIS studies.

The structure of the paper is as follows. Chapter 2 reviews TIS literature with a particular focus on relationships between TIS and sectors. Chapter 3 introduces our case and outlines methods and data. In Chapter 4 we analyze the implications of structural overlap with oil and gas sector 
on offshore wind TIS by structuring the analysis according to the four structural dimensions of technology, actors, networks and institutions. Chapter 5 discusses the main empirical findings and concludes.

\section{Literature review and a synthesis}

\subsection{Sector-TIS relationships}

The technological innovation system (TIS) framework was developed for studying emergence of new industries and/or knowledge fields (Carlsson \& Stankiewicz, 1991). A TIS is defined as a set of actors, networks, institutions and technology engaged in developing, diffusing and utilizing new products (goods and services) and processes related to a certain technological field or industry (Jacobsson \& Bergek, 2011). A characterizing feature of TIS analysis is the functions approach, i.e. conceptualizing different processes that support innovation and influence the build-up of an innovation system (Bergek et al., 2008a; Bergek et al., 2008b) (see Table 1 for overview). The central idea behind the focus on functions is that TIS performance cannot be reduced to the existence or absence of system components, as has been common in more traditional innovation system studies. The introduction of TIS functions constitutes an attempt to describe system dynamics in more detail. Functions can be understood as emergent properties of the interplay between actors and other components (Markard \& Truffer, 2008). Hence, networks, institutions and technology constitute the structural environment in which the activities of actors generate system dynamics. It is assumed that all functions should individually be rather strong for the TIS to progress.

However, a drawback of the TIS framework is that it is focused very much on single technologies which risks overlooking important interactions with other relevant technologies and sectors (Coenen \& Díaz López, 2010; Jacobsson \& Bergek, 2011; Markard \& Truffer, 2008). As Smith and Raven (2012, p. 1029) put it: "TIS tends not to highlight the interplay between the wider selection environment of an emerging system and internal system dynamics as an endogenous explanation in the emergence of that system". In response, TIS scholars have recently called for further attention to how TISs interact with different types of context, including other TISs, established sectors, geographical context, and politics (Bergek et al., 2015; Coenen, 2015; Kern, 2015; Andersen \& Markard, 2017). In this paper we contribute to narrowing this gap in the literature with a particular focus on sector-TIS interactions.

Recent studies have shown that established sectors can indeed exercise significant influence on an emerging TIS, understood here as a nascent industry. Wirth and Markard (2011) show how the formation of a biogas TIS in Switzerland benefitted from established sectors such as agriculture and forestry but also that prior industry routines and values (informal institutions) led to tensions in the TIS. Hanson (2017) illustrates how the established electrometallurgical industry provided a foundation for building a photovoltaic TIS in Norway. Also, Haley (2015) reports how structural overlaps between the established hydropower regime and electric vehicle TIS in Quebec have supported the growth of the latter through e.g. legitimacy benefits and knowledge development. We draw but also elaborate on these studies to articulate an extension of the TIS framework. 


\subsection{Structural overlaps}

In terms of the basic nature of linkages between established sectors and a TIS, two types of interaction can be distinguished: negative (competitive) and positive (complementary) (cf. Sandén \& Hillman, 2011; Wirth \& Markard, 2011). When negative relationship prevails, sector firms can attempt to block the growth of emerging industries. Positive relationships may take two main forms. First, emerging industries can feed on the demand for productivity-enhancing technologies from established sectors (Hirsch-Kreinsen et al., 2005). Second, actors from the established sector can see the emerging industry as a new promising business opportunity, and on entry, they bring various resources which fuel further progress.

In terms of the direction of influence, Bergek et al. (2015) distinguish between two types of linkages between a focal TIS and a sector. First, external links refer to 1-way influence from a context element on a TIS such as national institutions, politics, or sudden price shifts. Second, structural overlaps (or couplings) refer to a situation with shared components between a TIS and a sector, possibly resulting in a 2-way interaction where systems influence each other. The content of structural overlaps, and how they influence a focal TIS and a sector, is likely to change over time. For example, a TIS in its early and formative phase is characterized by entry of organizations, formation and early alignment of institutions, emergence of networks, and immature technology. These processes therefore necessarily draw on external sources e.g. more established sectors and infrastructure (Bergek et al., 2008b). However, if the TIS enters a growth phase with technology diffusing in a self-sustained way, feedback loops between the sector and the TIS may appear such that the TIS transforms the sector (Bergek et al., 2008a; Markard, 2016). The nature of the actual interaction is ultimately an empirical question, though. For example, in situations where a significant asymmetry remains between the systems in terms of size and maturity, influence may remain 1-way.

We define structural overlaps as components shared by the sector and the focal TIS. Sectors and TIS fundamentally have the same "texture" i.e. they can be conceptualized by the same analytical components: actors, networks, institutions, and technology (Markard \& Truffer, 2008). Structural overlaps influence the focal TIS' functions by facilitating different forms of resource redeployment from sector to TIS. Indeed, this is the main reason for analysing structural overlaps.

"Overlap actors", which could be e.g. firms, research institutes and public organizations, are per definition active in several industries. This is in contrast to dedicated actors which operate only in one industry. Many of the overlap actors are diversified firms venturing from established sectors into an emerging TIS. Diversifiers play a dual role. On the one hand, they may contribute positively to the TIS by for instance bringing with them various resources as new technologically related industries offer growth opportunities by use of e.g. existing knowledge (Penrose, 1959; Montgomery \& Hariharan, 1991). On the other hand, diversifiers are likely to continue pursuing activities also in their primary market. Diversifiers thus may abstain from full commitment to novel areas due to uncertainty or fear of cannibalizing existing activities (Geels et al., 2008). Thus, multiple overlaps with sectors might also constrain the TIS, e.g. through conflicting interests for firms present in two competing systems (Bergek et al., 2015). 
We define "institutional overlap" as institutions shared by the sector and focal TIS. We distinguish between formal and informal institutions. The former refers typically to visible and codified institutions such as regulations, standards and policies, and the latter to non-explicit aspects of organizations and industries such as routines, norms and visions. A TIS in a formative phase typically enjoys little support from formal institutions, thus making informal institutions of prime interest. Formal and informal institutions within a TIS interact and can be more or less (mis)aligned. The formation of a novel TIS requires the creation of new supporting institutions in a process where the wider institutional setup becomes aligned with its needs (Jacobsson \& Bergek, 2004). Success in such alignment is more likely if informal and formal institutions are also aligned within the TIS (Wirth et al., 2013). Firms need to commit and engage in collective efforts to achieve this alignment - to "run in packs" (Van De Ven, 1993; Musiolik et al., 2012). However, institutional alignment and collaboration can be compromised if actors hold diverse visions and expectations about the future - factors that define perceived problems and goals for the TIS (Smith et al., 2005). For instance, the informal institutions embedded in diversifying firms have been shaped by prior industry experience, but influence the decision-making also in the new market (Benner \& Tripsas, 2012).

"Network overlaps" are networks that connect actors across the focal TIS and the sector. Participation in such networks can provide access to novel information, knowledge, and other resources (Nahapiet \& Ghoshal, 1998), and may create opportunities for collaboration and institutional alignment.

"Technology overlaps" are knowledge and artefacts which are used in both sector and TIS. Technology is here understood as relevant knowledge bases underpinning the TIS and sector, but also artefacts and infrastructure. Technology overlaps enable the transfer of competences from one system to another by outlining the possibility to redeploy existing resources (Breschi et al., 2003). Such possibilities can even lead to a situation where strong and resourceful firms from an established sector dominate the emerging industry (Erlinghagen \& Markard, 2012). Nevertheless, having technology overlaps with established sectors strongly contributes to the development prospects of new industries (Boschma \& Frenken, 2011). Hence, the knowledge bases underpinning established sectors often serve as a selection environment for new industry formation (Hidalgo et al., 2007).

\subsection{Synthesis: an extended analytical framework}

The above literature review suggests that structural overlaps are important for facilitating flows of resources from sector to TIS, i.e. for creating positive relationships. By synthesizing our definitions of structural overlaps and their roles in sector-TIS interaction, we propose an extension of the TIS framework for analyzing such implications for a nascent TIS from relations with an established sector, cf. Figure 1.

Our approach has two main features. First, it explicitly distinguishes between sources of impact by differentiating between the different dimensions of structural overlap (actors, networks, technology and institutions). This is important as overlaps can have ambiguous effects on the focal TIS, i.e. positive effects of one type of overlap can mitigate negative effects of another, and vice versa. Second, the framework enables analysis of each how each individual overlap 
dimension impact different functions of the TIS. Our framework can therefore help to unpack the complexity of relationships between an established sector and a nascent TIS by identifying both the origin and content of implications from such relationships. The framework also distinguishes between the two phases of TIS development. Moreover, both sector and TIS are constantly influenced by other surrounding context elements, such as other sectors, technologies, geographical factors and politics.

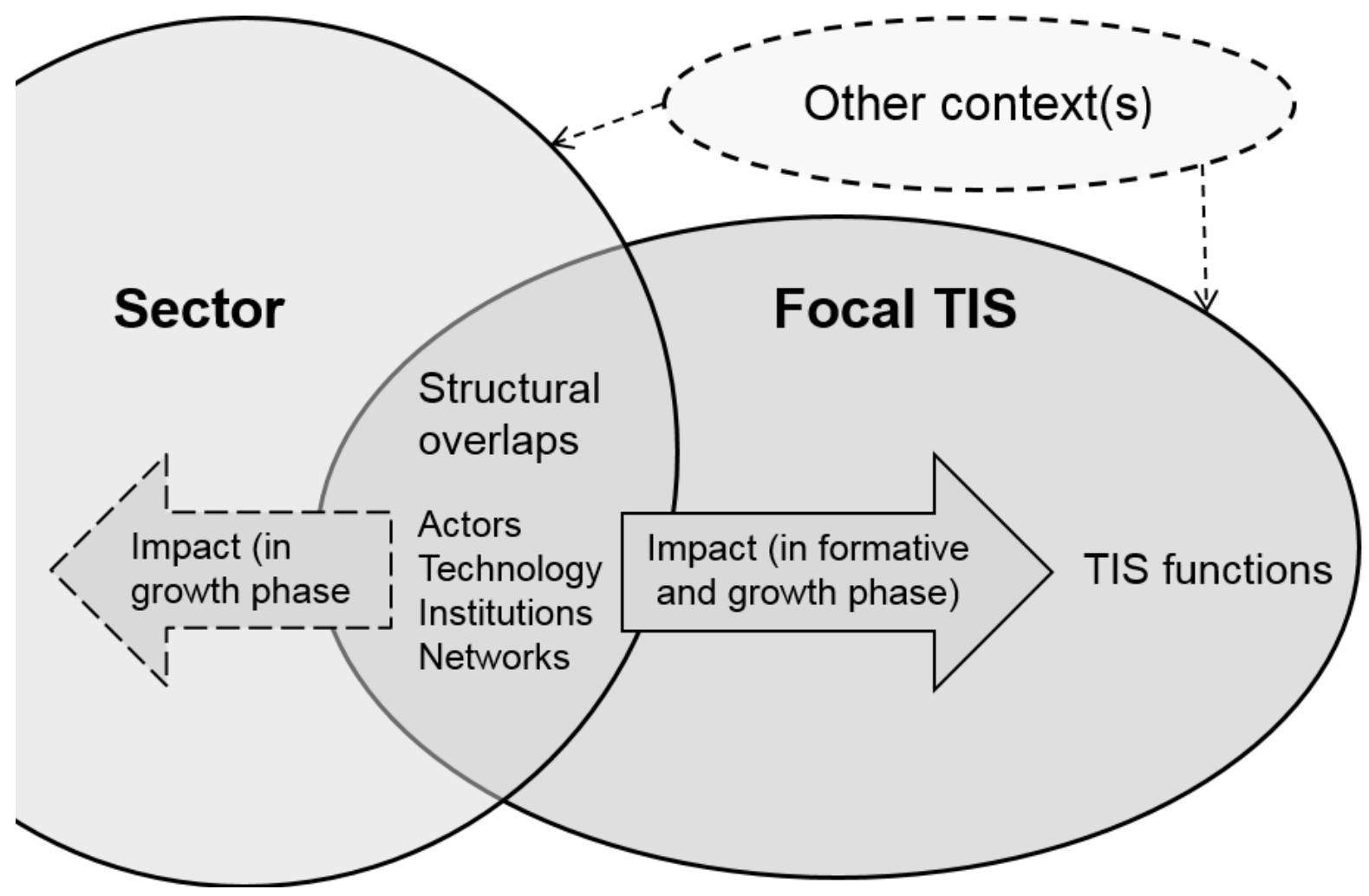

Figure 1 Analytical framework to study sector-TIS relationships.

\section{Case, methods and data}

\subsection{Case description}

\subsubsection{The Norwegian Oil and Gas sector}

The Norwegian oil and gas (O\&G) sector was established in the late 1960s and has since evolved through an interplay of international oil firms, Norwegian suppliers, large R\&D institutes (e.g. SINTEF) and universities, and supportive policies (e.g. local content requirements and $\mathrm{R} \& \mathrm{D}$ tax exemptions) orchestrated by, amongst others, the Norwegian Petroleum Directorate, Ministry of Oil and Energy, and Statoil (national oil company) (Engen, 2009; Saether et al., 2011). In 2015, the petroleum sector represented 15 per cent of Norwegian GDP and 39 per cent of total exports. Thus, upstream petroleum activities are very important to the Norwegian economy. In addition to petroleum exports, petroleum production on the Norwegian continental shelf has enabled the development of a large supply industry that today represents the second largest industry in Norway in terms turnover. Long-term participation in 
development of technologies for oil extraction in difficult weather conditions of the North Sea has made the supply industry competitive both in the Norwegian and the international offshore oil and gas markets. Most segments of the supply chain are technologically mature with established practices, standards, and dominant designs. The O\&G sector is volatile and goes through boom and bust periods. While rising oil prices since the early 2000s have resulted in high profits and cost levels in the sector, the most recent downturn in prices (since late 2014) has been pressing firms to cut cost and consider diversification (E24, 2016).

\subsubsection{The Norwegian offshore wind TIS}

Offshore wind power (OWP) in Norway is an emerging industry with promising prospects for market growth; especially in the North Sea (EWEA, 2015). Despite having some of the best offshore wind resources in Europe, Norway itself has limited installed capacity. As current electricity supply is $98 \%$ renewable, there are few possibilities for decarbonizing via deployment of more renewables without increasing demand (e.g. via electrifying transport and/or trading more with continental Europe) (Hanson et al., 2011; Gullberg, 2013).

The first plans for large-scale (bottom fixed) OWP in Norway came with the Havsul project in 2005. Shortly after, Statoil developed the floating OWP project Hywind Demo (a single fullscale turbine) to experiment with electrification of offshore $O \& G$ activities, but regulatory issues hindered it and the turbine was eventually connected to the mainland electricity grid in 2009 (Normann, 2015). It is by 2017 the only OWP project realized in Norway. Despite the absence of a Norwegian OWP market, about 150-200 Norwegian firms are involved in OWP, mostly in markets abroad (Steen \& Hansen, 2014; Normann \& Hanson, 2015). While political support for demo projects and a domestic market has been weak, R\&D activities have received more support via state actors such as Norwegian Research Council, Innovation Norway and Enova.

\subsection{Methods}

We performed an industry-level and single-country case study. A case study approach is suitable for such analysis as it allows an analysis of context specific processes (Yin, 2009). As was apparent above, the Norwegian O\&G sector and the OWP industry corresponds to our conceptualization of an established sector and a TIS in a formative phase. We explore their relationship by empirically assessing how overlaps with the $O \& G$ sector influence the functions of the OWP TIS. Previous research has indicated positive relationship between them (Steen \& Hansen, 2014). Hence, this case represents an opportunity for exploring positive sector-TIS relationships in more depth. The TIS framework can be applied for diagnostic assessments of TIS performance and functions within a short period of time. The key purpose of assessing system strengths and weaknesses is to inform policy makers about which of the functions need support to advance the TIS (see e.g. Bergek et al., 2008a; Andersen, 2014; Wieczorek et al., 2015). The framework is equally applicable for process studies of TIS building. In such studies, the assessment and interplay of functions over longer time spans is often central to explanatory accounts of TIS evolution (see e.g. Hekkert et al., 2007; Suurs \& Hekkert, 2009; Andersen, 2015). Both these approaches are inherently dynamic as they focus on analysis of processes unfolding over time (functions), albeit with different temporal scopes. Our analysis follows the 
former approach to TIS analysis by constituting an assessment of how an established sector has influenced a nascent TIS in the period 2005-2015.

Geographically we limited our analysis to Norway although both the O\&G and OWP are global industries. As innovation systems are inherently open and recursive, both the Norwegian O\&G sector and the OWP TIS can be understood as subsystems of these global supply chains with whose other subsystems they are intimately intertwined (Binz et al., 2014; Normann \& Hanson, 2017). In this paper, we focus on the relationship between these two specific subsystems. In foregrounding this relationship, we intentionally neglect possible influences from the wider and international industries in which these subsystems are embedded. We also exclude the influence that other context factors (cf. Figure 1) may have on the focal TIS. Although this rather narrow analytical focus is not suitable for a full assessment of the OWP TIS, it is indeed fitting for our partial TIS analysis because it allows us to closely examine whether and how the established sector supports or hinders the emergence of an OWP industry. Moreover, as we focus on a TIS in its formative phase we do not consider how the focal TIS influences the established sector.

\subsection{Process of analysis and description of data}

We approached our analysis in two steps. In the first step we identified the structural overlaps between the industries and collected information about their characteristics. Diverse firm level data (e.g. financial and ownership data) is publicly available in Norway (Brønnøysundregistrene), which offered good possibilities to investigate overlaps. We compiled a database of Norwegian firms active in OWP by gathering data from industry reports, industry organization memberships, $4 \mathrm{C}$ database and desk research. We found 161 OWP firms (firm sub-units excluded) out of which 22 firms focused mainly on OWP (referred to as dedicated firms). We collected employee and ownership data ${ }^{1}$. Additionally, we drew on a survey of OWP firms (response rate 109/183: 60\%, for details see Normann \& Hanson 2015) which collected information e.g. about the engagement with and expectations to OWP, and technology overlap with other sectors. Regarding O\&G, we used a database of 621 O\&G firms in Norway, collected by using reports from industry associations and clusters. By comparing our data material and performing desk research, we concluded with 107 overlap/diversified firms. We also investigated board interlocks between the two industries. By using Brønnøysundregistrene, we analyzed if the board directors of the 54 (161 minus 107, cf. above) remaining OWP firms held a director position in an O\&G firm. Additionally, we analyzed the membership lists of five Norwegian OWP networks and investigated how many of the member firms were active in $O \& G$ sector. In terms of institutional and technology overlaps, we analyzed survey results, OWP technology standards as well as secondary literature. Additionally, we searched and analyzed all Norwegian OWP related patents from Global Patent Index and determined the share of $O \& G$ firms as applicants ${ }^{2}$.

\footnotetext{
1 We included owner firms and public organizations until second degree (owners, and the owners of owners) which held at least $10 \%$ share of an OWP firm, and excluded private individuals. We used proff.no website.

2 We used CPC category Y02E10/70 (Wind energy) and its subcategories with offshore related key words (offshore, floating, buoyant, water, marine, sea and/or vessel).
} 
In the second step, we assessed and analyzed the implications of overlaps for TIS functions. This step called for methodological advancement. Prior TIS literature has identified indicators to assess the performance of functions (e.g. Vasseur et al., 2013; Bento \& Wilson, 2016) but has not yet adjusted these indicators for sector-TIS analysis. Therefore, we developed a set of indicators to evaluate such implications from overlaps at the function level (see Table 1). This was done by use of both inductive (i.e. emerging from the data) and deductive (i.e. discussed in prior TIS literature) exercises by the authors. Effects of overlaps are classified according to each of the TIS functions to perform an overall assessment of the sector-TIS relationship. However, due to lack of benchmarking, these evaluations were done in a rudimentary way, i.e. positive and negative influence without assessing the relative strength of the effects.

Table 1 Description of TIS functions and indicators of influence from overlaps. A=actors, I=institutions, N=networks, T=technology.

\begin{tabular}{|c|c|c|}
\hline Function & Definition & $\begin{array}{l}\text { Indicators (implications for TIS from overlap } \\
\text { with sector) }\end{array}$ \\
\hline $\begin{array}{l}\text { Knowledge } \\
\text { development and } \\
\text { diffusion (F1) }\end{array}$ & $\begin{array}{l}\text { Development and diffusion of knowledge. Includes } \\
\text { depth and breadth of different types of knowledge } \\
\text { (e.g. technological, scientific) and their evolution. }\end{array}$ & $\begin{array}{l}\text { TIS actors using prior experience and technology } \\
\text { from sector (A, T) } \\
\text { Patents developed by diversified firms (A) } \\
\text { Interlocking directorates and other networks } \\
\text { between sector and TIS (N) } \\
\text { TIS standards cite sector standards (I) } \\
\text { Transfer of governance practices from sector to } \\
\text { TIS (I) }\end{array}$ \\
\hline $\begin{array}{l}\text { Influence on the } \\
\text { direction of search } \\
\text { (F2) }\end{array}$ & $\begin{array}{l}\text { Strength of incentives/pressures to join the TIS, as } \\
\text { well as mechanisms directing the TIS through } \\
\text { competing technologies, applications and markets. }\end{array}$ & $\begin{array}{l}\text { Diversification of firms from sector to TIS (A) } \\
\text { The ease of transferability of diversifiers' } \\
\text { experiences from sector to TIS (T) } \\
\text { Existing customer networks from sector (N) }\end{array}$ \\
\hline $\begin{array}{l}\text { Entrepreneurial } \\
\text { experimentation } \\
\text { (F3) }\end{array}$ & $\begin{array}{l}\text { Uncertainty reduction through experimentation by } \\
\text { trying out different technological concepts and } \\
\text { applications where many technologies fail and few } \\
\text { are successful. }\end{array}$ & $\begin{array}{l}\text { Entrance of diversified firms (A) } \\
\text { TIS utilizing technological concepts from sector } \\
\text { (T) }\end{array}$ \\
\hline $\begin{array}{l}\text { Market formation } \\
\text { (F4) }\end{array}$ & $\begin{array}{l}\text { Activities which drive market formation through } \\
\text { different phases, starting from nursing markets and } \\
\text { ending in mass markets. }\end{array}$ & $\begin{array}{l}\text { Engagement of diversifiers in advocacy for } \\
\text { market formation }(\mathrm{A}, \mathrm{I})\end{array}$ \\
\hline Legitimation (F5) & $\begin{array}{l}\text { Social acceptance of technology and compliance } \\
\text { with relevant institutions. Processes of institutional } \\
\text { alignment, conformance and creation. }\end{array}$ & $\begin{array}{l}\text { Media attention on diversifiers' TIS activities (A) } \\
\text { Coordinated advocacy for TIS (A, I) }\end{array}$ \\
\hline $\begin{array}{l}\text { Resource } \\
\text { mobilization (F6) }\end{array}$ & $\begin{array}{l}\text { Ability to mobilize human and financial capital e.g. } \\
\text { to learning processes and investments. Also } \\
\text { includes artefacts and infrastructure. }\end{array}$ & $\begin{array}{l}\text { Sector investments in TIS (N) } \\
\text { Access to human capital of sector (A) } \\
\text { Access to artefacts and infrastructure (T) }\end{array}$ \\
\hline $\begin{array}{l}\text { Development of } \\
\text { positive } \\
\text { externalities (F7) }\end{array}$ & $\begin{array}{l}\text { Positive internal dynamics of TIS functions as well } \\
\text { as other positive externalities, e.g. pooled labor } \\
\text { markets, emergence of specialized goods and } \\
\text { services etc. }\end{array}$ & $\begin{array}{l}\text { Diversifiers' level of expectations (I) } \\
\text { Diversifiers' level of engagement (I) } \\
\text { Level of collective entrepreneurship (I) }\end{array}$ \\
\hline
\end{tabular}

We explain the influence of overlaps under four sub-sections in the next chapter, corresponding to the four dimensions of structural overlaps, and graphically summarize our analysis in Figure 2. In the Figure, we visualize the various influences from overlaps to functions as arrows. Each arrow is assigned a letter code (A, B, etc.) that corresponds to specific parts of our analysis in Chapter 4. We also provide a table which presents the content of each letter code, cf. Table 2. Functions are represented with a code starting with the letter "F" (F1, F2, etc., see Table 1). 


\section{Results: Implications of structural overlap for the offshore wind power TIS}

In the following, we present the implications of structural overlaps between the O\&G sector and the OWP TIS for the functions of our focal TIS. Figure 2 summarizes our analysis and serves as a guide to the reader, while Table 2 provides more detailed information about the impact.

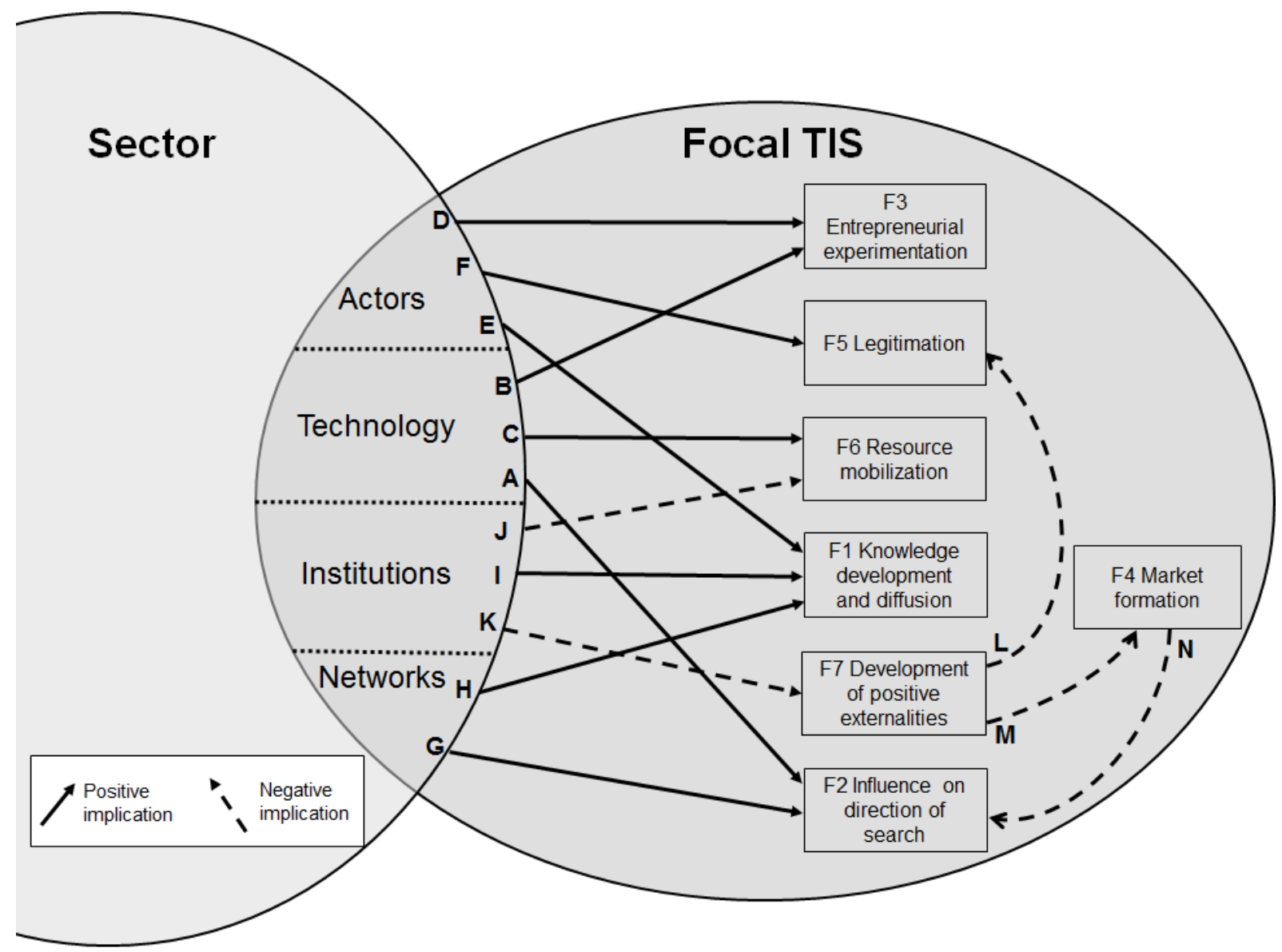

Figure 2 Main implications for OWP TIS from structural overlap with O\&G sector.

Table 2 Description of impact from structural overlap

\begin{tabular}{|l|l|l|l|l|}
\hline Code & Overlap & Impact & Function & Description of impact \\
\hline A & Technology & Positive & F2 & O\&G [offshore] knowledge applicable in OWP \\
\hline B & Technology & Positive & F3 & New OWP technologies inspired by O\&G sector \\
\hline C & Technology & Positive & F6 & Available O\&G infrastructure \\
\hline D & Actors & Positive & F3 & Diversifiers adapt to new market \\
\hline E & Actors & Positive & F1 & Diversifiers develop new knowledge \\
\hline F & Actors & Positive & F5 & Business and media attention regarding diversification \\
\hline G & Networks & Positive & F2 & Suppliers follow customers in a new market \\
\hline
\end{tabular}




\begin{tabular}{|l|l|l|l|l|}
\hline H & Networks & Positive & F1 & Board interlocks \\
\hline I & Institutions & Positive & F1 & OWP standards and governance draw on O\&G \\
\hline J & Institutions & Negative & F6 & Reluctance to commit resources \\
\hline K & Institutions & Negative & F7 & Lack of commitment and collective entrepreneurship \\
\hline L & Institutions & Negative & F5 & No coordinated, strong lobbying activity \\
\hline M & Institutions & Negative & F4 & Lack of push for support measures \\
\hline $\mathrm{N}$ & Institutions & Negative & F2 & Limited home market reduces attractiveness \\
\hline
\end{tabular}

\subsection{Technology overlaps}

OWP requires specialized skills and services related to offshore technologies and operations (Jacobsson \& Karltorp, 2012). Design, construction, transportation, installation and decommissioning of offshore objects are therefore fields where technology overlaps exist between OWP and O\&G. Many Norwegian firms in OWP draw on knowledge acquired in $O \& G$ and are concentrated in supply chain segments such as turbine and substation foundations, offshore operations and maintenance, and ocean meteorology, survey and subsea (see Table 2). This indicates that offshore competences acquired in $O \& G$ can form a knowledge base for dealing with maritime conditions also in the context of OWP. Consequently, OWP is able to tap into the best practices of $O \& G$ regarding "what works" in designing and installing offshore constructions. Such knowledge supports OWP e.g. in terms of reliability of technology. Hence, firms in O\&G with such relevant knowledge can redeploy their existing technologies and competences in OWP, which makes OWP an attractive industry to enter (F2, A).

For instance, in floating wind power technology, specific experience from $O \& G$ sector related to floating and mooring techniques and wave conditions can be utilized (DNV, 2013, pp. 118119). Moreover, turbine foundations, i.e. the construction fixed to the seabed which supports the turbine and the attached tower, use technology where knowledge transfers from O\&G to OWP have taken place. Most obvious examples are steel jacket foundations and tripods, attaching a turbine to the sea-bottom with three or four metal pillars, which have been used in $O \& G$ industry for decades, just in larger size. Another example is the gravity-based foundation of a dedicated OWP firm, Seatower, which reuses the condeep oil platform concept (a hollow concrete pile, instead of metal foundations), an innovation from the early days of Norwegian O\&G sector. Moreover, necessary technologies in OWP, such as dynamic positioning systems, motion compensated gangways for accessing towers, meteorological installations and offshore construction vessels were originally developed for offshore O\&G (Edwards, 2011). Hence, technology overlaps play a role in development of knowledge in the OWP TIS (F1) and influence experimentation with new designs and solutions (F3, B). Technology overlaps also enable transfer of labor from O\&G to OWP. 6 out of 10 dedicated OWP firms in our survey reported that their activities draw on experience from O\&G. As also reported by Steen and Hansen (2014), this suggests that the personnel of dedicated firms have previously worked in O\&G. Moreover, existing physical infrastructure developed for the purposes of $O \& G$, such as harbors and yards, have been mobilized to support activities in OWP (F6, C) (Steen \& Karlsen, 2014). 
Lastly, we note that the extent of technology overlap varies along the supply chain. For instance, a large share ( $46 \%)$ of diversified firms from O\&G industry were different types of maritime and offshore specialists, such as installation, sub-sea and shipping firms. Several consultancy, IT and R\&D firms were specialized in e.g. offshore structural design solutions. In comparison, only few diversified firms were related to top-side technologies, i.e. generators, blades etc., see Table 3.

Table 3: Share of OWP firms drawing on O\&G experiences ( $n=103)$.

\begin{tabular}{|c|c|c|c|c|c|c|c|c|}
\hline $\begin{array}{l}\text { Supply chain } \\
\text { segment }\end{array}$ & $\begin{array}{l}\text { Top- } \\
\text { side }\end{array}$ & Foundation & $\begin{array}{l}\text { Electrical } \\
\text { and grid }\end{array}$ & $\begin{array}{l}\text { Installation } \\
\text { \& vessels }\end{array}$ & $\begin{array}{l}\text { Ocean meteorology, } \\
\text { survey \& subsea }\end{array}$ & $\begin{array}{l}\text { Consultancy, } \\
I C T \& R \& D\end{array}$ & $\begin{array}{c}\text { Offshore } \\
\text { operations \& } \\
\text { maintenance }\end{array}$ & Other \\
\hline $\begin{array}{l}\% \text { of firms } \\
\text { using } \\
\text { experience } \\
\text { from O\&G } \\
\text { (n) }\end{array}$ & $\begin{array}{l}44 \% \\
(9)\end{array}$ & $93 \%$ (14) & $44 \%$ (9) & $48 \%$ (27) & $64 \%(11)$ & $60 \%(20)$ & $71 \%(7)$ & $\begin{array}{l}50 \% \\
(6)\end{array}$ \\
\hline
\end{tabular}

\subsection{Actor overlaps}

TIS actors consist of firms, educational organizations, public bodies and varied interest organizations (Bergek et al., 2008a). However, in a small economy as the Norwegian, the rather few research organizations and universities tend to be involved in everything which complicates the analysis of actor overlaps. For this reason, we focus our actor analysis primarily on firms.

The majority of firms in Norwegian OWP industry ( $66 \%$ or 107 firms) have diversified from O\&G. As mentioned above, many of them draw on prior experiences in O\&G to compete in OWP. However, knowledge and equipment used in O\&G often need to be adapted to the OWP market. $68 \%$ of the diversified firms $(n=41)$ reported that only minor adaptations were needed while $15 \%$ reported that major changes were necessary. This shows that diversifying firms are engaged in experimentation focused on adaptation and development of products and services to OWP (F3, D). Diversified firms are furthermore active in patenting. Of all 65 Norwegian OWP patents, $42 \%$ were held by diversified firms from O\&G. In combination with the above activities, this highlights that diversification of $O \& G$ firms has strengthened knowledge development in the OWP TIS (F1, E).

Diversified firms were, on average, larger and older than O\&G firms in general. $28 \%$ of diversified firms were large enterprises with more than 500 Million NOK annual turnover and had 1997 as median founding year, while same figures for all 621 O\&G firms in our database were $19 \%$ and 2000, respectively. ${ }^{3}$ Due to their sheer size and status in the national economy, the active involvement of firms such as Statoil, Fred. Olsen and Kværner, enhances the attractiveness of an emerging market in the eyes of a wider business community and public at large (Hansen \& Steen, 2015). For instance, Statoil's endeavors to develop OWP technologies have broadly attracted national media attention. Therefore, the entry of large O\&G firms has strengthened the general legitimacy of the OWP TIS (F5, F).

\footnotetext{
${ }^{3}$ In contrast, dedicated OWP firms in Norway were all micro-sized enterprises with less than 20M NOK annual revenue in 2013.
} 
The share of fulltime employees dedicated to OWP in diversified O\&G firms was generally low. $60 \%$ of diversified firms had less than $10 \%$ of their employees dedicated to OWP. However, in large firms even a small share of employees can amount to significant resources, and some were heavily engaged in OWP with more than 100 employees. We also found out that $41 \%$ of dedicated OWP firms were partly owned by O\&G firms, indicating investments in OWP start-ups. These overlaps thus illustrate transfer and mobilization of human and financial resources in OWP (F6). However, considering the vast resources available in the O\&G industry, and the incentivizing technological overlaps between the industries (cf. code A), this overall mobilization of resources from O\&G to OWP can be seen as meager.

\subsection{Network overlaps}

When important O\&G firms (such as Statoil and Kværner) have entered OWP, supplier firms - whose businesses are intimately linked to the activities and investments of large O\&G firms - have felt encouraged to diversify as well (Hansen \& Steen, 2015). Such O\&G customer networks have therefore incentivized to follow their main clients into the OWP market $(F 2, G)$. Also, 64\% of dedicated OWP firms had board interlocks with O\&G firms, which constitute a network connecting the industries. Shared board members thus act as knowledge brokers between O\&G and OWP, enabling transfer of tacit knowledge e.g. in terms of value chain management and export (F1, H). Such knowledge flows can be an asset for young firms (O' Hagan \& Green, 2002). However, when it comes to activities of diversified firms in OWP networks, such strong overlaps are not as evident. Despite forming the majority of OWP firms, diversified firms are the minority in all of the five identified OWP networks (see Table 4). Steen and Hansen (2014) reported that diversified O\&G firms prefer bilateral over multilateral relationships in e.g. R\&D collaboration. This refers to differences between O\&G and OWP in routines. Such institutional issues are elaborated further in the next section.

Table 4 Share of diversified firms in five OWP networks (November 2015).

\begin{tabular}{cccccc}
\hline Network & NORCOWE & NOWITECH & Arena NOW & Windcluster Mid-Norway & INTPOW \\
\hline $\begin{array}{c}\text { Diversified } \\
\text { firms in } \\
\text { networks }\end{array}$ & $25 \%(2 / 8$ firms $)$ & $42 \%(5 / 12)$ & $8 \%(1 / 12)$ & $33 \%(18 / 55)$ & $47 \%(8 / 17)$ \\
\hline
\end{tabular}

\subsection{Institutional overlaps}

As is often the case for emerging industries, the OWP TIS in Norway is characterized by limited formation of own institutions that, instead, are in a state of emergence. Partly for this reason, we observed only limited institutional overlap. However, we did note that some formal institutions such as OWP standards build on accumulated experience from O\&G sector. For instance, the OWP standards of DNV GL (a central maritime/O\&G classification and

\footnotetext{
${ }^{4}$ In 2017 INTPOW was merged with INTSOK, creating a new organisation called Norwegian Energy Partners.
} 
certification organization in Norway) make reference to offshore $O \& G$ standards ${ }^{5}$. For example, 40 of the 46 references cited by the DNV OS-J101 standard on OWP turbine support structure are O\&G related (Simonsen, (2015). Overlaps could also be observed in terms of governance. For instance, when giving concessions to OWP projects, the Norwegian government applies similar procedure as it developed in the 1960s for giving concessions to O\&G explorations (Ryggvik, 2010). Moreover, diversified firms often apply same safety norms in OWP as they are accustomed to in O\&G (Ollestad, 2011). The fact that both firms and regulating bodies can draw on institutionalized practices from $O \& G$ to build new institutions in OWP contributes to and accelerates knowledge development and diffusion in the OWP TIS $(\mathrm{F} 1, \mathrm{I})$.

We furthermore observe overlap in informal institutions regarding those embodied in diversified $O \& G$ firms whose firm identity, expectations and routines have been shaped in the $O \& G$ sector. Regarding expectations to OWP, diversified $O \& G$ firms fall into two categories. First, firms that can easily use extant products from O\&G in OWP (e.g. logistics) see OWP as a market for delivering generic offshore services requiring only minor adaptations of routines when moving from O\&G to OWP (cf. code D). Second, firms, that need more demanding adaptation of their products and routines, see OWP as a distant but promising future market as oil eventually declines (Edwards, 2011; Hansen \& Steen, 2015). In comparison, dedicated OWP firms hold much higher expectations to OWP as a growth industry and an opportunity to innovate in the short term (see Figure 3).

In addition, diversified firms predominantly see OWP as an auxiliary market - particularly important due to inherent volatility of oil markets - which should not affect the core activities in O\&G (Steen \& Hansen, 2014). These firms thus preserve their corporate identity as O\&G firms despite diversification activities. The volatility of the $O \& G$ sector includes upturns offering exceptionally high profits and downturns that generate crisis and bankruptcy. While downturns in O\&G increase interest in alternative markets such as OWP, upturns in O\&G tend to lure them back with a promise of high profits (Mäkitie et al., 2017). Many firms have institutionalized such volatility in their business practice and routines (Sraml Gonzalez, 2017). One implication of this is that their engagement in alternative markets often remain intermittent or fickle. Moreover, diversified firms often find it difficult to communicate and work with dedicated firms in OWP projects due to differences in industry routines and cultural backgrounds (Hansen \& Steen, 2015). Also, as mentioned above, diversified firms tend to prefer bilateral partnership over multilateral networks in R\&D collaboration (Steen \& Hansen, 2014).

5 Standards analyzed: DNV-OS-J101, DNV-OS-J103, DNV-OS-J201 and DNV-OS-J301. 


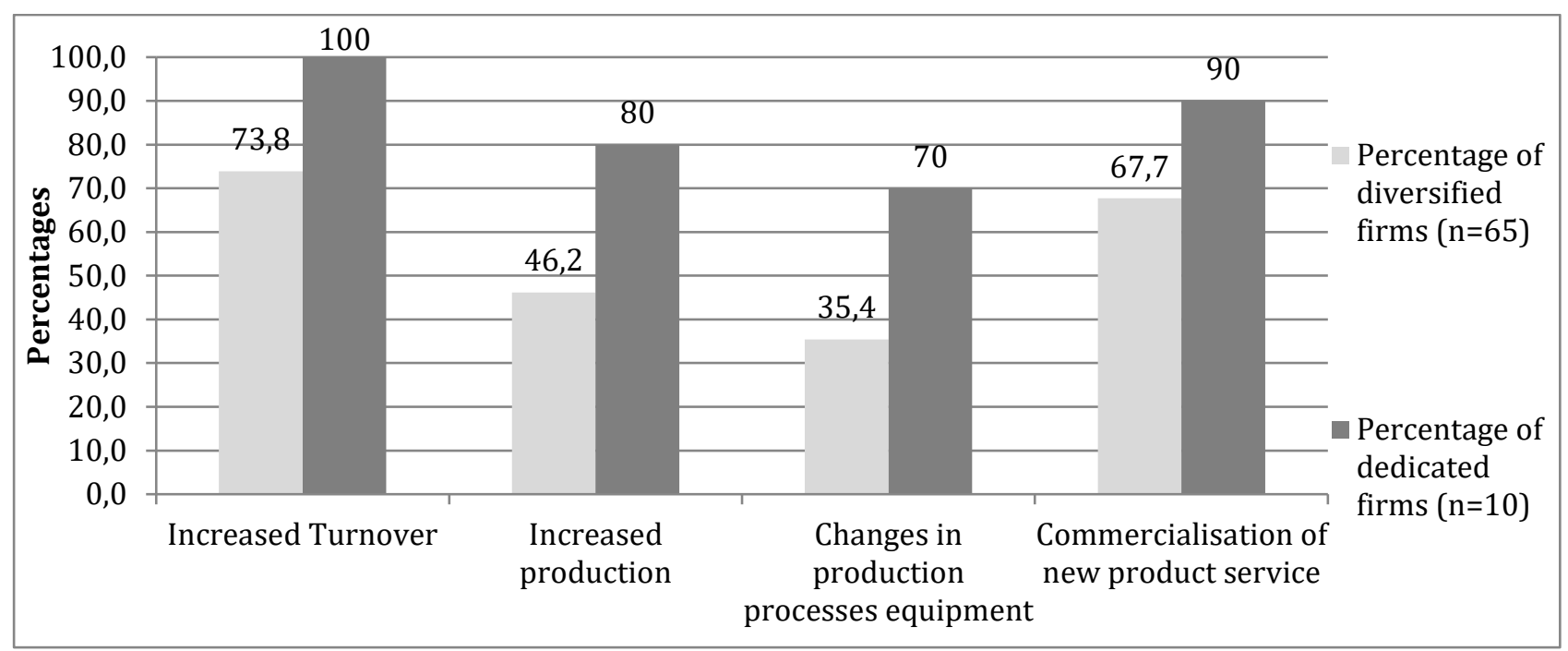

Figure 3 OWP firms' expectations to own performance in the OWP market for the next three years (percentages, source: survey).

Combined, these differences in expectations, identity, and routines indicate a misalignment of informal institutions among firms in the OWP TIS. This has two main implications. First, at the firm level, the expectations and identity of diversified O\&G firms suggest that they are currently, in contrast to dedicated firms, reluctant to channel major resources into promoting OWP technologically and institutionally. The reluctance of diversified firms to commit to OWP counteracts several of the otherwise positive influences noted above by e.g. thwarting the readiness to mobilize resources (F6, J) and hindering knowledge development and diffusion e.g. in networks (cf. sub-chapter 4.3).

Second, at the collective level, differences in expectations and identity imply that TIS actors do not share common visions and goals, and do not see the same problems and opportunities. Combined with the discrepancy in firms' collaboration routines, the latter is inhibiting the formation of strong networks in an emerging industry (Bergek et al., 2008b). The misalignment in informal institutions therefore also undermines collective entrepreneurship ("running in packs") required for creating new institutions and system building (Musiolik et al., 2012). For instance, lack of a home market is a challenge for most OWP firms, especially small and medium sized enterprises (SMEs) (Normann \& Hanson, 2017). The failure to promote a domestic market indicates that OWP does not enjoy sufficient legitimacy e.g. among policy makers and other influential industry actors. Indeed, Normann (2015) reports that creation of home market for OWP has been inhibited by "weak networks" among OWP actors in Norway. We infer that the misalignment of informal institutions among OWP firms and the associated inability to orchestrate collective entrepreneurship partially explains the absence of policies beyond R\&D instruments (cf. Normann, 2017).

Thus, the combination of modest commitment of O\&G firms and weak collective entrepreneurship negatively influences the formation of positive externalities in the OWP TIS (F7, K) which, in turn, influence other TIS functions by hindering the formation of "virtuous circles" of development within the OWP TIS. Especially, first, it inhibits the creation of widespread legitimacy e.g. via coordinated lobbying (F5, L). Second, partly as a consequence of the former, it negatively affects the prospects for market creation in Norway (F4, M) and 
therefore complicates commercialization of OWP technology developed with support from domestic R\&D. Third, weak market formation in Norway, in turn, reduces the general attractiveness of OWP for O\&G firms (especially SMEs) $(\mathrm{F} 2, \mathrm{~N})$ which further limits their commitment and redeployment of resources.

\section{Conclusions}

In this final chapter, we discuss and summarize the results of our empirical analysis, discuss implications for policy, and reflect on the usefulness and limitations of our analysis and framework.

\subsection{Key empirical findings}

Our empirical analysis shows that structural overlaps in technology, actors, and networks have had positive influences on TIS formation. Indeed, the Norwegian OWP TIS can be seen to have branched out from the O\&G sector (Steen \& Hansen, 2014). However, the key finding of our analysis is that these positive influences have been constrained by misaligned informal institutions that negatively influenced firms' commitment and collective entrepreneurship. Diversified firms, constituting the majority of firms in Norwegian OWP, consider themselves first and foremost as O\&G firms with OWP acting as an auxiliary market of secondary importance. Therefore, they employ strategies in OWP that are not sufficiently conducive for new industry formation in the Norwegian context, and do not commit to nurturing it. This is aggravated by the fact that many $O \& G$ diversifiers with international experience orient themselves towards non-Norwegian OWP markets. They thereby leave the task of institution building to the smaller, dedicated OWP firms (Normann \& Hanson, 2017). In addition, diversifiers' engagement in OWP is often only intermittent (Mäkitie et al., 2017). This implies that the O\&G sector's volatility transmits from sector to TIS causing instability in terms of actor commitment in the latter. Such diversification strategies may be rational from the perspective of individual $O \& G$ firms, but are less fruitful from an industry formation and institution building point-of-view. Low commitment combined with contrasting preferences for interaction modes among OWP firms furthermore obstruct the formation of strong networks thereby stalling collective entrepreneurship or "running in packs" (Van De Ven, 1993) necessary for e.g. domestic market formation and lobbying for legitimacy. We thus observe that the tensions arising from institutional overlaps negatively influence the overall performance of the TIS and impede the emergence of "virtuous circles" of development in the TIS.

\subsection{Analysing sector-TIS overlaps}

The starting point for this paper was to examine the prospects of established sectors contributing to accelerating climate change mitigation efforts. This would take place via redeploying resources from sector to the development of cleantech industries. In order to engage with this theme, we formulated an analytical framework that can be used to assess such situations. We drew and expanded upon recent developments in the TIS framework regarding relationships 
between a focal TIS and its context, with a particular focus on established sectors (Bergek et al., 2015; Wirth \& Markard, 2011). We applied the framework to analyze how overlaps between the Norwegian oil \& gas sector $(\mathrm{O} \& \mathrm{G})$ and the offshore wind industry have influenced the formation and early developments of the latter.

We found out that our proposed framework is valuable as it enabled analysis and assessment of the different ways how an established sector influences the processes of TIS formation. The framework opens up and nuances the notion of inter-industry relationships by considering four types of structural overlaps. By connecting the overlaps to TIS functions, it provides a detailed scheme for assessing how these relationships influence TIS formation. As such, the framework offers analysts an approach for managing the complexities associated with inter-industry relationships. For instance, our analysis illustrates that technology overlap is important but insufficient in itself for facilitating industry formation, and instead, mismatching institutions are constraining broad reallocation of resources from sector to TIS. Hence, the framework aids us to see the importance of multidimensional view in investigating resource redeployment between sector and TIS, accentuating the role of actors, institutions and networks, and not merely of technology and knowledge. As discussed above, the empirical results emerging from our case study suggests that especially institutional overlaps are highly influential regarding to what extent resources are redeployed from sector to TISs. We call for further studies to explore whether this is true also in other empirical contexts.

Our analysis shows that structural overlaps do not automatically lead to resource redeployment, but rather represent opportunities for it to materialize. This suggests that positive relationships between industries are ultimately executed by actors. Therefore, without committed agency, structural overlaps e.g. in terms of technology may well exist without notable redeployment of resources from sector to TIS. This insight is a further testament to the importance of closely inspecting how different types of overlaps influence TIS functions. In other words, our framework and analysis can assist in achieving a more complete view of the influence established sectors have on emerging industries, which, in turn, is necessary for designing effective policies to support resource redeployment to cleantech industries.

As a consequence of our analytical choices, our analysis, framework and results have several limitations that, in turn, also constitute opportunities for further advancement in TIS studies. First, our analysis has not explicitly considered how the influence of a sector on a TIS evolves over time. Hence, we call for further longitudinal process studies to explore such dynamics in sector-TIS interactions in more detail. Second, our study has been limited to a TIS in a formative phase. Further studies could investigate whether characteristics of sector-TIS interactions are different in the growth phase. Third, when assessing sector-TIS interaction, explicitly incorporating transnational dimensions of both sector and focal TIS is a relevant extension which should be considered. Fourth, our analysis has focused solely on the direct influence from an established sector. A more complete analysis would combine the sector-TIS analysis with a full assessment of the focal TIS, including other relevant contexts, such as other TISs and sectors. 


\subsection{Policy implications}

Our results point to four main policy implications. First, when the dominant firms in an emerging industry are diversifiers from an established sector, it is challenging to make all firms equally committed to the new industry and to engage in collective entrepreneurship to create new institutions and to facilitate resource redeployment. This suggests that it is important for new industry formation that a sound balance between diversifying established firms and newcomers exists. Hence, policy should equally support diversification efforts of established as well as the formation of new firms.

Second, our analysis also suggests that a diversification opportunity alone for firms in established sectors might not be a sufficient incentive to secure their full commitment to the new market. Diversification is a costly endeavor and, e.g. due to mismatching institutions, firms can easily be deterred from taking on board such risks. Hence, policies intending to encourage a large-scale redeployment of resources from established sectors to cleantech industries should include a mix of different policy measures. Alongside introducing classical "pull" mechanisms, such as supporting formation of new promising industries, additional measures could include reducing support for diversifiers' primary market. For example, discontinuing public support for $O \& G$ activities by reducing incentives for exploration of new oil extraction areas, could make firms more serious about diversification and institution building in other markets, such as OWP. In sum, in this context policies that support emerging cleantech industries need to be seen in conjunction with policies that affect the profitability of activities in the established sectors. Kivimaa and Kern (2016) suggest that such "push" policies could include cutting R\&D funding, removing subsidies and tax deductions, or balancing involvement of incumbents in policy advisory councils.

Third, even if misaligned institutions do not form a critical barrier, and firms from an established sector are "willing" diversifiers, they face risk and uncertainty in the new market. We suggest that further policy measures could reduce the cost of diversification by facilitating resource transfers between industries by mitigating the risks involved. This could include establishing "safe corridors" between a sector and an emerging industry for example by offering subsidies for staff re-training, engagement in networks or other investments necessary for diversification.

Finally, our findings indicate that solely relying on diversifiers for redeployment of resources from sector to TIS is not sufficient. Other channels such as entrepreneurship, spin-off firms, or labor mobility would be less likely to suffer from the institutional barriers identified in this paper. A mix of policies, which broaden the set of channels for resource transfer, could therefore further support formation of positive relationships between sectors and emerging industries.

\section{Authorship}

Tuukka Mäkitie (TM) and Allan D. Andersen (ADA) contributed equally in developing the conceptual arguments and empirical analysis of this research article with support from other authors. TM, Håkon E. Normann and Jens Hanson performed empirical data collection with 
support from ADA and Taran M. Thune. All authors have contributed in developing the discussion and conclusions of this paper.

\section{Acknowledgements}

Funding: This work was supported by the Research Council of Norway (grant numbers 237677 , 209697). We are grateful for the three anonymous referees for their constructive critique. Moreover, we would like to thank Volker Hoffman, Desirée Pacheco, Anne Rainville and other participants of ETH Academy on Sustainability and Technology 2016, as well as Jochen Markard, Teis Hansen and Olav Wicken for their valuable comments on prior versions of this paper.

\section{References}

Andersen, A. D. (2014). No transition without transmission: HVDC electricity infrastructure as an enabler for renewable energy? Environmental Innovation and Societal Transitions, 13, 75-95. doi:10.1016/j.eist.2014.09.004

Andersen, A. D. (2015). A functions approach to innovation system building in the South: the pre-Proálcool evolution of the sugarcane and biofuel sector in Brazil. Innovation and Development, 5(1), 1-21. doi:10.1080/2157930x.2014.996855

Andersen, A. D., \& Markard, J. (2017). Innovating incumbents and technological complementarities: How recent dynamics in the HVDC industry can inform transition theories. Working Papers on Innovation Studies, 20170612. Retrieved from https://ideas.repec.org/p/tik/inowpp/20170612.html

Benner, M. J., \& Tripsas, M. (2012). The influence of prior industry affiliation on framing in nascent industries: the evolution of digital cameras. Strategic Management Journal, 33(3), 277-302. doi:10.1002/smj.950

Bento, N., \& Wilson, C. (2016). Measuring the duration of formative phases for energy technologies. Environmental Innovation and Societal Transitions, 21, 95-112. doi:http://dx.doi.org/10.1016/j.eist.2016.04.004

Bergek, A., Hekkert, M., Jacobsson, S., Markard, J., Sandén, B., \& Truffer, B. (2015). Technological innovation systems in contexts: Conceptualizing contextual structures and interaction dynamics. Environmental Innovation and Societal Transitions, 16, 51 64. doi:http://dx.doi.org/10.1016/j.eist.2015.07.003

Bergek, A., Jacobsson, S., Carlsson, B., Lindmark, S., \& Rickne, A. (2008a). Analyzing the functional dynamics of technological innovation systems: A scheme of analysis. Research Policy, 37(3), 407-429. doi:10.1016/j.respol.2007.12.003

Bergek, A., Jacobsson, S., \& Sandén, B. A. (2008b). 'Legitimation' and 'development of positive externalities': two key processes in the formation phase of technological innovation systems. Technology Analysis \& Strategic Management, 20(5), 575-592. doi:10.1080/09537320802292768

Berggren, C., Magnusson, T., \& Sushandoyo, D. (2015). Transition pathways revisited: Established firms as multi-level actors in the heavy vehicle industry. Research Policy, 44(5), 1017-1028. doi:10.1016/j.respol.2014.11.009

Binz, C., Truffer, B., \& Coenen, L. (2014). Why space matters in technological innovation systems-Mapping global knowledge dynamics of membrane bioreactor technology. Research Policy, 43(1), 138-155. doi:10.1016/j.respol.2013.07.002 
Boschma, R., \& Frenken, K. (2011). Technological relatedness, related variety and economic geography. In P. Cooke, B. T. Asheim, R. Martin, D. Schwartz, \& F. Tödling (Eds.), Handbook of regional innovation and growth: Edward Elgar.

Breschi, S., Lissoni, F., \& Malerba, F. (2003). Knowledge-relatedness in firm technological diversification. Research Policy, 32(1), 69-87. doi:http://dx.doi.org/10.1016/S00487333(02)00004-5

Carlsson, B., \& Stankiewicz, R. (1991). On the nature, function and composition of technological systems. Journal of Evolutionary Economics, 1(2), 93-118. doi:10.1007/BF01224915

Coenen, L. (2015). Engaging with changing spatial realities in TIS research. Environmental Innovation and Societal Transitions, 16(Supplement C), 70-72. doi:https://doi.org/10.1016/j.eist.2015.07.008

Coenen, L., \& Díaz López, F. J. (2010). Comparing systems approaches to innovation and technological change for sustainable and competitive economies: an explorative study into conceptual commonalities, differences and complementarities. Journal of Cleaner Production, 18(12), 1149-1160. doi:10.1016/j.jclepro.2010.04.003

Dewald, U., \& Achternbosch, M. (2016). Why more sustainable cements failed so far? Disruptive innovations and their barriers in a basic industry. Environmental Innovation and Societal Transitions, 19, 15-30. doi:http://dx.doi.org/10.1016/j.eist.2015.10.001

DNV. (2013). DNV-OS-J103 Design of Floating Wind Turbine Structures: Det Norske Veritas AS.

E24. (2016, 2 September 2016). Oljeleverandører søker fiskelykken. Retrieved from http://e24.no/naeringsliv/ons-oljemessen/oljeleverandoerer-soeker-fiskelykken-satserstort-paa-oppdrett-offshore/23780982

EC. (2016). Accelerating Clean Energy Innovation. (COM(2016) 763 final). Brussels: European Commission Retrieved from http://ec.europa.eu/energy/sites/ener/files/documents/1_en_act_part1_v6_0.pdf.

Edwards, I. (2011). Overcoming Challenges for the Offshore Wind Industry and Learning from the Oil and Gas Industry. Retrieved from Scotland, UK: http://www.powercluster.net/Portals/6/Offshore\%20wind\%20report\%200vercoming\%20Challenges $\% 20$ for\%20the\%200ffshore\%20Wind\%20Industry.pdf

Engen, O. A. (2009). The development of the Norwegian petroleum innovation system : a historical overview. In J. Fagerberg, D. C. Mowery, \& B. Verspagen (Eds.), Innovation, Path Dependency and Policy. The Norwegian Case (pp. 387). Oxford: Oxford University Press, 2009.

Erlinghagen, S., \& Markard, J. (2012). Smart grids and the transformation of the electricity sector: ICT firms as potential catalysts for sectoral change. Energy Policy, 51, 895906. doi:http://dx.doi.org/10.1016/j.enpol.2012.09.045

EWEA. (2015). Offshore wind. Retrieved from http://www.ewea.org/policy-issues/offshore/

Geels, F. W., Hekkert, M. P., \& Jacobsson, S. (2008). The dynamics of sustainable innovation journeys. Technology Analysis \& Strategic Management, 20(5), 521-536. doi:10.1080/09537320802292982

Gullberg, A. T. (2013). The political feasibility of Norway as the 'green battery' of Europe. Energy Policy, 57, 615-623. doi:http://dx.doi.org/10.1016/j.enpol.2013.02.037

Haley, B. (2015). Low-carbon innovation from a hydroelectric base: The case of electric vehicles in Québec. Environmental Innovation and Societal Transitions, 14, 5-25. doi:10.1016/j.eist.2014.05.003

Hansen, G. H., \& Steen, M. (2015). Offshore oil and gas firms' involvement in offshore wind: Technological frames and undercurrents. Environmental Innovation and Societal Transitions, 17, 1-14. doi:http://dx.doi.org/10.1016/j.eist.2015.05.001 
Hanson, J. (2017). Established industries as foundations for emerging technological innovation systems: The case of solar photovoltaics in Norway. Environmental Innovation and Societal Transitions. doi:http://dx.doi.org/10.1016/j.eist.2017.06.001

Hanson, J., Kasa, S., \& Wicken, O. (2011). Energirikdommens paradokser : innovasjon som klimapolitikk og naeringsutvikling. Oslo: Universitetsforl.

Hekkert, M. P., Suurs, R. A. A., Negro, S. O., Kuhlmann, S., \& Smits, R. E. H. M. (2007). Functions of innovation systems: A new approach for analysing technological change. Technological Forecasting \& Social Change, 74(4), 413-432. doi:10.1016/j.techfore.2006.03.002

Hess, D. J. (2013). Industrial fields and countervailing power: The transformation of distributed solar energy in the United States. Global Environmental Change, 23(5), 847-855. doi:http://dx.doi.org/10.1016/j.gloenvcha.2013.01.002

Hidalgo, C. A., Klinger, B., Barabasi, A. L., \& Hausmann, R. (2007). The product space conditions the development of nations. Science, 317(5837), 482-487. doi:10.1126/science. 1144581

Hirsch-Kreinsen, H., Jacobsson, D., Laestadius, S., \& Smith, K. (2005). Low and medium technology industries in the knowledge economy: the analytical issues. In H. HirschKreinsen, D. Jacobson, S. Laestadius, \& K. Smith (Eds.), Low-tech innovation in the knowledge economy. Frankfurt, Germany: Peter Land.

Hockerts, K., \& Wüstenhagen, R. (2010). Greening Goliaths versus emerging Davids Theorizing about the role of incumbents and new entrants in sustainable entrepreneurship. Journal of Business Venturing, 25(5), 481-492. doi:http://dx.doi.org/10.1016/j.jbusvent.2009.07.005

IEA. (2016). Energy Technology Perspectives 2016. Towards Sustainable Urban Energy Systems. Retrieved from http://www.iea.org/bookshop/719Energy_Technology_Perspectives 2016

Jacobsson, S., \& Bergek, A. (2004). Transforming the energy sector: the evolution of technological systems in renewable energy technology. Industrial and Corporate Change, 13(5), 815-849. doi:10.1093/icc/dth032

Jacobsson, S., \& Bergek, A. (2011). Innovation system analyses and sustainability transitions: Contributions and suggestions for research. Environmental Innovation and Societal Transitions, 1(1), 41-57. doi:10.1016/j.eist.2011.04.006

Jacobsson, S., \& Karltorp, K. (2012). Formation of competences to realize the potential of offshore wind power in the European Union. Energy Policy, 44, 374-384. doi:http://dx.doi.org/10.1016/j.enpol.2012.01.069

Kern, F. (2015). Engaging with the politics, agency and structures in the technological innovation systems approach. Environmental Innovation and Societal Transitions, 16(Supplement C), 67-69. doi:https://doi.org/10.1016/j.eist.2015.07.001

Kivimaa, P., \& Kern, F. (2016). Creative destruction or mere niche support? Innovation policy mixes for sustainability transitions. Research Policy, 45(1), 205-217. doi:http://dx.doi.org/10.1016/j.respol.2015.09.008

Mäkitie, T., Normann, H. E., Sraml Gonzalez, J., \& Thune, T. M. (2017). The green fling: The role of market volatility in incumbent industries' engagement in sustainability transitions. Paper presented at the The 8th International Sustainability Transitions Conference, Gothenburg, Sweden.

Markard, J. (2016). Conceptualizing the life cycle of technological innovation systems. Paper presented at the 7th International Sustainability Transitions Conference, Wuppertal, Germany. 
Markard, J., Raven, R., \& Truffer, B. (2012). Sustainability transitions: An emerging field of research and its prospects. Research Policy, 41(6), 955-967. doi:10.1016/j.respol.2012.02.013

Markard, J., \& Truffer, B. (2008). Technological innovation systems and the multi-level perspective: Towards an integrated framework. Research Policy, 37(4), 596-615. doi:http://dx.doi.org/10.1016/j.respol.2008.01.004

Montgomery, C. A., \& Hariharan, S. (1991). Diversified expansion by large established firms. Journal of Economic Behavior \& Organization, 15(1), 71-89. doi:http://dx.doi.org/10.1016/0167-2681(91)90005-I

Musiolik, J., Markard, J., \& Hekkert, M. (2012). Networks and network resources in technological innovation systems: Towards a conceptual framework for system building. Technological Forecasting and Social Change, 79(6), 1032-1048. doi:10.1016/j.techfore.2012.01.003

Nahapiet, J., \& Ghoshal, S. (1998). Social Capital, Intellectual Capital, and the Organizational Advantage. The Academy of Management Review, 23(2), 242-266. doi:10.2307/259373

Normann, H. E. (2015). The role of politics in sustainable transitions: The rise and decline of offshore wind in Norway. Environmental Innovation and Societal Transitions, 15, 180-193. doi:10.1016/j.eist.2014.11.002

Normann, H. E. (2017). Policy networks in energy transitions: The cases of carbon capture and storage and offshore wind in Norway. Technological Forecasting and Social Change, 118, 80-93. doi:http://dx.doi.org/10.1016/j.techfore.2017.02.004

Normann, H. E., \& Hanson, J. (2015). Exploiting global renewable energy growth. Opportunities and challenges for internationalisation in the Norwegian offshore wind and solar energy industries. Retrieved from https://www.ntnu.no/documents/7414984/202064323/Norwegian+OWP+and+PV+rep ort++01.12.2015.pdf/

Normann, H. E., \& Hanson, J. (2017). The role of domestic markets in international technological innovation systems. Industry and Innovation, 1-23. doi:10.1080/13662716.2017.1310651

O' Hagan, S. B., \& Green, M. B. (2002). Tacit knowledge transfer via interlocking directorates: A comparison of Canada and the United States. Geografiska Annaler: Series B, Human Geography, 84(1), 49-63. doi:10.1111/j.0435-3684.2002.00113.x

Ollestad, B. (2011). Beredskapsmetodikk $i$ havvind. Kan lardom tas fra petroleumsindustrien? (Master thesis), University of Stavanger.

Penrose, E. (1959). The theory of the growth of the firm. Oxford: Blackwell.

Ryggvik, H. (2010). The Norwegian Oil experience: A toolbox for managing resources? Retrieved from www.sv.uio.no/tik/forskning/publikasjoner/tikrapportserie/Ryggvik.pdf

Saether, B., Isaksen, A., \& Karlsen, A. (2011). Innovation by co-evolution in natural resource industries: The Norwegian experience. Geoforum, 42(3), 373-381. doi:10.1016/j.geoforum.2011.01.008

Sandén, B. A., \& Hillman, K. M. (2011). A framework for analysis of multi-mode interaction among technologies with examples from the history of alternative transport fuels in Sweden. Research Policy, 40(3), 403-414. doi:10.1016/j.respol.2010.12.005

Simonsen, R. M. (2015). Standardization as an innovation strategy: Bringing down costs of offshore wind. (Master of Society, Science and Technology in Europe Master thesis), Univesity of Oslo. 
Smink, M. M., Hekkert, M. P., \& Negro, S. O. (2015). Keeping sustainable innovation on a leash? Exploring incumbents' institutional strategies. Business Strategy and the Environment, 24(2), 86-101. doi:10.1002/bse.1808

Smith, A., \& Raven, R. (2012). What is protective space? Reconsidering niches in transitions to sustainability. Research Policy, 41(6), 1025-1036. doi:http://dx.doi.org/10.1016/j.respol.2011.12.012

Smith, A., Stirling, A., \& Berkhout, F. (2005). The governance of sustainable socio-technical transitions. Research Policy, 34(10), 1491-1510. doi:http://dx.doi.org/10.1016/j.respol.2005.07.005

Sraml Gonzalez, J. (2017). Sustaining innovation in a captive buyer-supplier relationship during an industry downturn: The role of captive suppliers. Under review in a scientific journal.

Steen, M., \& Hansen, G. H. (2014). Same Sea, Different Ponds: Cross-Sectorial Knowledge Spillovers in the North Sea. European Planning Studies, 22(10), 2030-2049. doi:10.1080/09654313.2013.814622

Steen, M., \& Karlsen, A. (2014). Path creation in a single-industry town: The case of Verdal and Windcluster Mid-Norway. Norsk Geografisk Tidsskrift - Norwegian Journal of Geography, 68(2), 133-143. doi:10.1080/00291951.2014.894564

Suurs, R. A. A., \& Hekkert, M. P. (2009). Cumulative causation in the formation of a technological innovation system: The case of biofuels in the Netherlands.

Technological Forecasting and Social Change, 76(8), 1003-1020. doi:http://dx.doi.org/10.1016/j.techfore.2009.03.002

Van De Ven, H. (1993). The development of an infrastructure for entrepreneurship. Journal of Business Venturing, 8(3), 211-230. doi:http://dx.doi.org/10.1016/08839026(93)90028-4

Vasseur, V., Kamp, L. M., \& Negro, S. O. (2013). A comparative analysis of Photovoltaic Technological Innovation Systems including international dimensions: the cases of Japan and The Netherlands. Journal of Cleaner Production, 48, 200-210. doi:http://dx.doi.org/10.1016/j.jclepro.2013.01.017

Wesseling, J. H., \& Van der Vooren, A. (2017). Lock-in of mature innovation systems: the transformation toward clean concrete in the Netherlands. Journal of Cleaner Production, 155, 114-124. doi:http://dx.doi.org/10.1016/j.jclepro.2016.08.115

Wieczorek, A. J., Hekkert, M. P., Coenen, L., \& Harmsen, R. (2015). Broadening the national focus in technological innovation system analysis: The case of offshore wind. Environmental Innovation and Societal Transitions, 14, 128-148. doi:10.1016/j.eist.2014.09.001

Wirth, S., \& Markard, J. (2011). Context matters: How existing sectors and competing technologies affect the prospects of the Swiss Bio-SNG innovation system. Technological Forecasting and Social Change, 78(4), 635-649. doi:10.1016/j.techfore.2011.01.001

Wirth, S., Markard, J., Truffer, B., \& Rohracher, H. (2013). Informal institutions matter: Professional culture and the development of biogas technology. Environmental Innovation and Societal Transitions, 8, 20-41. doi:http://dx.doi.org/10.1016/j.eist.2013.06.002

Yin, R. K. (2009). Case study research : design and methods (4th ed. Vol. 5). Thousand Oaks, Calif: Sage. 